\title{
Seguridad ciudadana y los sistemas de videovigilancia. Límites, garantías y regulación*
}

\author{
María Nieves de la Serna Bilbao* \\ Recibido: 15 de mayo de 2016 • Aprobado: 10 de junio de 2016
}

\section{Resumen}

Las nuevas tecnologías han producido cambios insospechados y han planteado para el derecho innumerables retos. Uno de ellos es el que suscita la videovigilancia, cuya finalidad, entre otras muchas, es ofrecer mayor seguridad a los ciudadanos. El uso de estos sistemas por parte de las Fuerzas y Cuerpos de Seguridad como un instrumento para prevenir alteraciones de la seguridad ciudadana en lugares públicos suscitó muchos interrogantes, en especial, la vulneración que el uso de tales sistemas puede plantear al derecho a la intimidad en sentido amplio. Para legitimar su uso y evitar que se produzcan injerencias del poder público en el "derecho a la vida" de las personas en España, fue aprobada la denominada Ley de Videovigilancia, texto legal que constituye el marco normativo aplicable a la utilización de los sistemas de grabación de imágenes y sonidos por las Fuerzas y Cuerpos de Seguridad en el cumplimiento de las competencias encomendadas por la Constitución española respecto de la protección del libre ejercicio de los derechos y libertades, todo ello en aras a la protección de la seguridad ciudadana.

\footnotetext{
${ }^{\wedge}$ El presente artículo es resultado de la producción académica generada por el convenio suscrito entre la Universidad Santo Tomás (sede Bogotá) y la Universidad Carlos III de Madrid. El proyecto de investigación al que se adscribe el presente artículo es "E1 Estado Social en la Encrucijada: Limitaciones, condiciones y mejoras en la prestación de los servicios públicos”-DER2015-70883-P-, del Ministerio de Economía y Competitividad de España.DOI: http://dx.doi.org/10.15332/s1900-0448.2016.0045.06

${ }^{*}$ Doctora en Derecho por la Universidad Carlos III de Madrid, premio extraordinario de doctorado. Profesora titular de Derecho Administrativo del Departamento de Derecho Público del Estado de la Universidad Carlos III de Madrid desde 1991 hasta la actualidad. Subdirectora del Máster Universitario en Derecho de las Telecomunicaciones, Protección de Datos, Audiovisual y Sociedad de la Información desde el año 2000 hasta la actualidad. Secretaria académica de la Facultad de Ciencias Sociales y Jurídicas de la Universidad Carlos III de Madrid desde 2008 hasta la actualidad. Investigadora del Instituto Pascual Madoz de Ordenación del Territorio, Urbanismo y Medio Ambiente de la mencionada Universidad. Correo electrónico: nieves.delaserna@uc3m.es
} 
Palabras clave: seguridad ciudadana, Orden público, Fuerzas y Cuerpos de Seguridad, Videovigilancia, autorización de sistemas de videovigilancia, Ley de Videovigilancia.

\title{
Public security and video surveillance systems. Limits, GUARANTEES AND REGULATION
}

\begin{abstract}
New technologies have produced unexpected changes and has raised countless challenges to the law. One of them is the video surveillance raises aimed, among many others, is to provide greater security for citizens. The use of these systems by the Forces of Security as a tool to prevent disturbances of public safety in public places raised many questions, especially the violation that the use of such systems can give rise to the right to privacy broad sense. To legitimize their use and prevent interference of public power produced in the "right to life" of people, it was approved in Spain the so-called law of video surveillance legal text that constitutes the regulatory framework applicable to the use of recording systems images and sounds by the Security Forces in fulfilling the tasks entrusted by the Spanish Constitution concerning the protection of the free exercise of rights and freedoms. All this in order to protect public safety.
\end{abstract}

Keywords: Citizen Security, Public Order, Security Forces, Surveillance, authorization of video surveillance systems, video surveillance law

\section{SEgurança CidAdã E os Sistemas de VideovigilânCia. LiMiTES, GARANTIAS E REGULAÇÃo}

\section{Resumo}

As novas tecnologias têm produzido mudanças inusitadas e tem apresentado para o direito inúmeros desafios. Um deles é suscitado pela videovigilância, cuja finalidade, entre muitas, é oferecer maior segurança aos cidadãos. $\mathrm{O}$ uso destes sistemas pelas forças e corpos de segurança como um instrumento para prevenir alterações da segurança cidadã em lugares públicos suscitou muitos interrogantes, em particular, a vulneração que o uso de tais sistemas pode apresentar ao direito à intimidade em sentido amplo. 
Para legitimar seu uso e evitar que surjam ingerências do poder publico no "direito à vida" das pessoas em Espanha, foi aprovada a Lei de Videovigilância, texto legal que constitui o marco normativo aplicável na utilização dos sistemas de gravação de imagens e sons pelas Forças e corpos de segurança no cumprimento das obrigações estabelecidas pela constituição espanhola respeito da proteção do livre exercício dos direitos e liberdades, tudo em favor da proteção da segurança cidadã.

Palavras-chave: segurança cidadã, ordem pública, Forças e Corpos de Segurança, Videovigilância, autorização de sistemas de videovigilância, Lei de Videovigilância.

\section{Introducción}

Como es sabido, uno de los principios básicos en materia de seguridad es la competencia del Estado. En efecto, le corresponde a este salvaguardar la seguridad interior y exterior del país. Estamos, pues, ante una actividad de cometido exclusivamente público-estatal ${ }^{1}$, así lo ha destacado la doctrina administrativa más autorizada. En este sentido, el profesor Parejo Alfonso afirma que el monopolio estatal del uso de la violencia y de la coacción debe ser definido como uno de los fundamentos mismos de toda vida social políticamente organizada. Ahora bien, para los poderes públicos aquel monopolio conlleva la obligación de asumir un deber de defensa y de protección frente a los peligros que amenazan el buen orden de la vida social, deber de defensa que necesariamente tiene naturaleza y rango constitucionales. Por esta razón, el profesor Parejo Alfonso señala que la seguridad y el orden público son valores que están en constante tensión dialéctica con la libertad, y cuyos términos y conflictos se resuelven por la ley con arreglo al sistema sustantivo y material diseñado por la propia Constitución española -en adelante, $\mathrm{CE}-$. La libertad y la seguridad se presentan, pues, como un binomio en constante tensión dialéctica. Corresponde a los poderes públicos garantizar la efectiva realización de los derechos y libertades de las personas, pero también les compete asegurar la seguridad pública. Se trata de un bien constitucional de primer orden que además constituye el presupuesto mismo para el efectivo disfrute de los derechos.

${ }^{1}$ Parejo Alfonso (1996, pp. 99 y ss.) destaca que desde la Declaración de Derechos del Hombre y de los Ciudadanos de 1789, dicho principio se encuentra asumido por nuestra sociedad en el artículo 12: "La garantía de los derechos del hombre y del ciudadano necesita de una fuerza pública; por lo tanto, esta fuerza ha sido instituida en beneficio de todos, y no para el provecho particular de aquellos a quienes ha sido encomendada", principio que vino a superar el primitivo sistema de "autotutela". 
Es preciso destacar que el uso de las modernas tecnologías, en particular, la instalación de sistemas de videovigilancia por parte de los poderes públicos como instrumento para garantizar aquella seguridad pública ha incidido de manera importante en este contexto y ha planteado diversas cuestiones. Por un lado, si bien resulta incuestionable que el uso de aquellos sistemas ofrecen importantes ventajas en la actividad de prevención y persecución del delito, así como en el mantenimiento del buen orden, por otro al mismo tiempo, su uso determina también un sacrificio de no pocos derechos y libertades garantizados constitucionalmente.

Este trabajo, por tanto, se centrará en estudiar la utilización por parte del poder público de aquellos sistemas de videovigilancia en aras a garantizar la seguridad pública y el orden público, su regulación, principios, límites y demás cuestiones de interés.

\section{La seguridad y el orden público como exigencia del orden jurídico}

Como destaca el profesor Parejo Alfonso (2011, pp.103 y ss.), la seguridad existe cuando el orden púbico se confunde con el orden jurídico. Como desataca -citando a A Posada-, la seguridad es aquella situación de normalidad en que se mantiene y vive un Estado cuando se desarrollan las diversas actividades individuales y colectivas sin que se produzcan perturbaciones. De ahí que cuando se da la situación de seguridad -desde un punto de vista jurídico-administrativo- no es necesaria la existencia de la acción de policía, pues la finalidad de esta es hacer efectivo el deber de los ciudadanos de no perturbar el buen orden de la cosa pública. La función de policía es, entonces, perseguir y mantener dicho buen orden público, evitando o suprimiendo las acciones o los hechos perturbadores o nocivos para la seguridad. Con tal fin, comprende todas aquellas actuaciones que necesariamente pueden conducir a tal situación.

Teniendo en cuenta lo anterior, el orden y la seguridad pública son al mismo tiempo una exigencia del orden jurídico que reclama una tranquilidad y una seguridad externa mínima para la vida social y, a la vez, una consecuencia de dicho orden. Un orden público y una seguridad ciudadana solo son posibles en el marco de un preciso orden jurídico establecido ${ }^{2}$. Recordemos que, desde el punto de vista del

${ }^{2}$ El profesor Parejo Alfonso (1996) que la seguridad ciudadana se identifica, siguiendo a Hauriou, con el orden material y exterior considerado como un estado de hecho opuesto al desorden, con el estado de paz opuesto al estado de perturbación. 
orden y de la seguridad pública, tienen gran relevancia, pero destacan especialmente, los derechos fundamentales y las libertades públicas, y más específicamente, los derechos a la vida y a la integridad física y moral (art. 15), a la intimidad personal y familiar, al honor e imagen junto con la inviolabilidad del domicilio y la protección de datos (art. 18); la libre circulación y residencia (art. 19), la reunión pacífica (art. 21), paricularmente la libertad y seguridad personales (art. $17 \mathrm{CE}$ ), toda vez que este último se puede considerar la base, el marco y el presupuesto de los anteriores.

En consecuencia, la actividad administrativa de policía se identifica con una actividad que incide en los derechos fundamentales y en las libertades públicas, ello por dos razones:

- En primer lugar, porque la seguridad y el orden público persiguen prevenir los riesgos y peligros que se ciernen sobre los bienes y derechos constitucionales, así como afrontar y suprimir las perturbaciones que puedan suceder, pero solo limitado a aquel que derive de y se justifique en la Constitución.

- En segundo, porque la seguridad y el orden público inciden necesariamente en la libertad y en los derechos fundamentales de los ciudadanos para garantizarles la posición fundamental que les asegura el valor superior de la dignidad de la persona y el libre desarrollo de la personalidad proclamado en el artículo 10 de la CE.

Pues bien, de lo hasta aquí dicho resulta que la acción administrativa de la policía del orden público se concreta en los siguientes aspectos:

- Por un lado, en las medidas de prevención de perturbaciones, dentro de las cuales se comprende el uso de los sistemas de videovigilancia.

- Por otro, en las medidas de represión de perturbaciones y, por tanto, en la coacción (empleo de la fuerza) y la sanción.

La Ley Orgánica 4/2015, de 30 de marzo, de protección de la seguridad ciudadana(en adelante, LOPSC), recuerda, en este sentido, que la seguridad ciudadana constituye una garantía para que los derechos y las libertades reconocidos y amparados por las constituciones democráticas puedan ser ejercidos libremente por la ciudadanía y no se queden en meras declaraciones formales carentes de eficacia jurídica -razón por la cual, la seguridad ciudadana se configura como uno de los elementos esenciales del Estado de derecho-. De acuerdo con lo anterior, las demandas sociales de seguridad ciudadana se dirigen esencialmente al Estado, en cuanto existe una conciencia social de que solo aquel puede asegurar un ámbito de convivencia en el que sea posible el ejercicio de los derechos y libertades mediante 
la eliminación de la violencia y la remoción de los obstáculos que se opongan a la plenitud de aquellos.

Define también a la seguridad ciudadana y la seguridad pública -ambos conceptos recogidos en la Constitución (artículos 104.1 y 149.1.29. ${ }^{\text {a }}$ )-como actividades dirigidas a la protección de personas y bienes y al mantenimiento de la tranquilidad ciudadana, señalando, acto seguido, que la seguridad ciudadana nunca puede justificar una intervención expansiva del Estado sobre los ciudadanos en virtud de peligros indefinidos. Siempre es necesario concretar los ámbitos de la intervención policial con el fin de evitar una discrecionalidad administrativa excesiva y una potestad sancionadora genérica. En definitiva, para garantizar la seguridad ciudadana, que constituye una de las prioridades de la acción de los poderes públicos, el modelo de Estado de derecho instaurado por la $\mathrm{CE}$ dispone de tres mecanismos:

- Un ordenamiento jurídico adecuado para dar respuesta a los diversos fenómenos ilícitos.

- Un Poder Judicial que asegure su aplicación.

- Unas Fuerzas y Cuerpos de Seguridad eficaces en la prevención y persecución de las infracciones.

De ahí que cualquier actuación de aquellos sujetos habilitados para mantener el orden público -como es precisamente la instalación de sistemas de videovigilancia- debe cumplir necesariamente con aquellos cometidos y ser respetuoso con la legalidad vigente.

\section{La seguridad ciudadana y las fuerzas y cuerpos de seguridad}

El artículo 104 de la CE habilita a las Fuerzas y Cuerpos de Seguridad del Estado, bajo la dependencia del Gobierno, a proteger el libre ejercicio de los derechos y libertades reconocidos y amparados por la $\mathrm{CE}$ y a garantizar la seguridad ciudadana con el fin de que dichos derechos y libertades puedan ser ejercidos libremente por los ciudadanos. De ahí que, como hemos señalado, la seguridad ciudadana se configure como uno de los elementos esenciales del Estado de derecho ${ }^{4}$.

\footnotetext{
${ }^{3}$ El texto constitucional utiliza dos conceptos: el de seguridad ciudadana (en el artículo 104.1) y el de seguridad pública (artículo 149.1.29a), conceptos que, de acuerdo con la Exposición de Motivos de la LOPSC, tanto la doctrina como la jurisprudencia han venido interpretando "con matices" como sinónimos.

${ }^{4}$ Corresponde en este caso diferenciar, como lo hace la propia Constitución, entre las Fuerzas Armadas (mencionadas en el artículo 8 CE) y las Fuerzas y Cuerpos de Seguridad (artículo 104 CE),
} 
Recordemos que los conceptos de libertad y seguridad constituyen un binomio clave para el buen funcionamiento de toda sociedad democrática avanzada, siendo la seguridad un instrumento al servicio de la garantía de derechos y libertados y no un fin en sí mismo. Como ya nos consta, la seguridad existe cuando el orden público se confunde con el orden jurídico mientras que este define la seguridad, y su custodia corresponde a unos órganos concretos.

La seguridad pública o seguridad ciudadana-expresiones utilizadas tanto por la jurisprudencia como por la doctrina como sinónimas, si bien con algunos maticesfue definida tempranamente por el Tribunal Constitucional como "una actividad dirigida a la protección de personas y bienes y al mantenimiento de la tranquilidad $\mathrm{u}$ orden de los ciudadanos, que engloba un conjunto plural y diversificado de actuaciones, distintas por su naturaleza y contenido, orientadas a una misma finalidad tuitiva del bien jurídico así definido" 5 .

El propio artículo 104 de la CE determina que una ley con rango orgánico debe determinar las funciones, los principios básicos de actuación y los estatutos de las Fuerzas y Cuerpos de Seguridad, mandato que, conjuntamente con el recogido en el artículo 149.1.29. a del mismo texto constitucional, reconoce la competencia exclusiva del Estado en el mantenimiento de la Seguridad Pública, correspondiendo su actuación al Gobierno de la nación, a las comunidades autónomas y a las corporaciones locales, dentro de los principios básicos de actuación de las Fuerzas y Cuerpos de Seguridad ${ }^{6}$. Se habilita así un concreto cuerpo como vigilante de la seguridad, sujeto a instrucciones del Gobierno (nacional, autonómico o local), con la función de mantener la seguridad pública - distinta de la actividad de policía judicial-. Recordemos que el Tribunal Constitucional ha dicho que “...las Fuerzas de Policía están al servicio de la comunidad para garantizar al ciudadano el libre y pacífico ejercicio de los derechos que la Constitución y la Ley les reconoce, y este es el sentido del artículo 104.1 CE (...) configurando a la Policía como un servicio público para la comunidad, especializado en la prevención y lucha contra

en tanto que se trata de dos instituciones distintas, con un régimen jurídico diferente contenido en distintas Leyes Orgánicas.

${ }^{5}$ Véase en este sentido la STC 33/1982 de 8 de junio.

${ }^{6}$ De acuerdo con el artículo 2 de la LFCS, “Son Fuerzas y Cuerpos de Seguridad: a) Las Fuerzas y Cuerpos de Seguridad del Estado dependientes del Gobierno de la nación. b) Los Cuerpos de Policía dependientes de las Comunidades Autónomas. c) Los Cuerpos de Policía dependientes de las Corporaciones Locales". 
la criminalidad, el mantenimiento del orden y la seguridad pública y la protección del libre ejercicio de los derechos y libertades..."7.

El cuerpo de Policía para la seguridad ciudadana, en sentido estricto, tiene como finalidad, pues, realizar todas las actividades posibles para perseguir e impedir la comisión de infracciones contra la regulación jurídico-pública de la seguridad y orden público, y en tal sentido puede utilizar, en los términos establecidos por la legislación correspondiente, los sistemas de videovigilancia y en su caso aplicar las sanciones administrativas que correspondan. Se trata, como certeramente apunta el profesor Parejo Alfonso, de proteger a la ciudadanía, de prevenir los riesgos de perturbación de la tranquilidad ciudadana que no alcanzan, sin embargo, el reproche penal. Este último plano de actuación corresponde a la denominada Policía Judicial, que tiene por finalidad tutelar el orden jurídico-penal, ámbito distinto materialmente del anterior en cuanto su actuación depende del Poder Judicial, opera bajo aquella autoridad judicial con el objetivo de investigar hechos infractores tipificados en el Código Penal, detener a los infractores, aportar pruebas de la infracción penal, etc. No obstante, a pesar de las diferencias apuntadas, no existe siempre una delimitación clara y precisa entre ambas esferas de actuación (Policía de Seguridad y Policía Judicial) en cuanto en la realidad existen zonas de relación recíproca dado que se trata de proteger el orden jurídico establecido ${ }^{8}$.

${ }^{7}$ STC 55/1990 de 28 de marzo.

${ }^{8}$ El artículo 11 de la LOFCS señala las funciones de las Fuerzas y Cuerpos de Seguridad, del siguiente modo

Artículo 11

1. Las Fuerzas y Cuerpos de Seguridad del Estado tienen como misión proteger el libre ejercicio de los derechos y libertades y garantizar la seguridad ciudadana mediante el desempeño de las siguientes funciones:

a) Velar por el cumplimiento de las Leyes y disposiciones generales, ejecutando las órdenes que reciban de las Autoridades, en el ámbito de sus respectivas competencias.

b) Auxiliar y proteger a las personas y asegurar la conservación y custodia de los bienes que se encuentren en situación de peligro por cualquier causa.

c) Vigilar y proteger los edificios e instalaciones públicos que lo requieran.

d) Velar por la protección y seguridad de altas personalidades.

e) Mantener y restablecer, en su caso, el orden y la seguridad ciudadana.

f) Prevenir la comisión de actos delictivos.

g) Investigar los delitos para descubrir y detener a los presuntos culpables, asegurar los instrumentos, efectos y pruebas del delito, poniéndolos a disposición del Juez o Tribunal competente, y elaborar los informes técnicos y periciales procedentes.

h) Captar, recibir y analizar cuantos datos tengan interés para el orden y la seguridad pública, y estudiar, planificar y ejecutar los métodos y técnicas de prevención de la delincuencia. 
La delimitación de las funciones y competencias que corresponden a la Policía de Seguridad viene dada por la mencionada LOPSC, por la Ley Orgánica 2/1986, de 13 de marzo de Fuerzas y Cuerpos de Seguridad -en adelante, LFCS- y por otras normas sectoriales. A todas ellas se deben sumar las distintas normas autonómicas. Sin embargo, como señala la Exposición de Motivos de la LFCS "la seguridad pública constituye una competencia difícil de parcelar, toda vez que no admite delimitaciones o definiciones, con el rigor y precisión admisibles en otras materias". Y ello porque nos encontramos ante una materia en la que las normas ordenadoras no contemplan realidades físicas tangibles, sino, más bien, eventos meramente previstos para el futuro, respecto de los cuales se ignora el momento, el lugar, la importancia y, en general, las circunstancias y condiciones de aparición. De ahí que la actividad de seguridad pública esté construida, en su mayor parte, con conceptos jurídicos indeterminados y que existan unas muy variadas potestades administrativas, habilitaciones genéricas (vigilar, custodiar, proteger, etc.) o específicas de actos administrativos y de normativas que inciden directamente en la esfera jurídica de los ciudadanos, además del ejercicio, en su caso, de la coacción o fuerza física para la ejecución de sus actos y potestad sancionadora. Dentro de ellas se encuentra, desde luego, el uso de los sistemas de videovigilancia siempre, claro está, dentro de los límites y las concreciones establecidas por la ley que regula su uso por las Fuerzas y Cuerpos de Seguridad del Estado, como es la Ley Orgánica 4/1997, de 4 de agosto, reguladora de la utilización de videocámaras por las Fuerzas y Cuerpos de Seguridad en lugares públicos, en adelante, LOV.

\section{La seguridad ciudadana y el uso de la tecnología, en particular, los sistemas de videovigilancia}

Como ya hemos señalado, para materializar la seguridad ciudadana, las Fuerzas y Cuerpos de Seguridad del Estado no pueden ni deben hacer un uso ilimitado de sus facultades. El propio Tribunal Constitucional se ha encargado de concretar su ámbito, propio de lícita actuación, al destacar que no resulta posible legitimar la realización por parte de las autoridades públicas de facultades ilimitadas con el pretexto de garantizar el orden público para reprimir arbitrariamente todo tipo de

i) Colaborar con los Servicios de Protección Civil en los casos de grave riesgo, catástrofe o calamidad pública, en los términos que se establezcan en la legislación de Protección Civil. 
conductas con la excusa del mantenimiento del orden público,. Tampoco resulta posible justificar cualquier actuación de las citadas organizaciones que, en aras de lograr la seguridad ciudadana, permita privar de los derechos a las personas bajo el pretexto de la eficacia de la acción policial o, en general, del mantenimiento de la seguridad y orden públicos. Por todo ello, el Alto Tribunal recuerda que "la eficacia en la persecución del delito, cuya legitimidad es incuestionable, no puede imponerse, sin embargo, a costa de los derechos y libertades fundamentales".

Muy por el contrario, la intervención de las Fuerzas y Cuerpos de Seguridad del Estado se debe realizar con pleno cumplimiento de la legalidad vigente, sin que su actuación pueda dar lugar a una intervención expansiva sobre los ciudadanos para salvaguardarles de peligros indefinidos. Aquellas fuerzas no deben, bajo ningún punto de vista, actuar discrecionalmente ni tampoco ejercer potestades sancionadoras genéricas, por más que la "sociedad del riesgo" así lo exija ${ }^{10}$.

No hace falta destacar que, después de que hayan sucedido diversos atentados terroristas (11 de septiembre de 2001en Nueva York, 11 de marzo de 2004 en Madrid, 7 de junio de 2005 en Londres, más recientemente 13 de noviembre en París y 22 de marzo de 2016 en Bruselas), una de las principales preocupaciones de los ciudadanos es la seguridad pública. Se reclama por parte de la sociedad una mayor eficacia policial y judicial, así como también la adopción de ciertas políticas públicas -más conocidas como "tolerancia cero"-, situación que ha llevado a la búsqueda de la seguridad como prioridad a nivel mundial, por un lado, para luchar contra la delincuencia, pero, por otro, también para proteger los bienes y los derechos de las personas. En aras del cumplimiento de dicho objetivo, ha adquirido un especial protagonismo el uso de la tecnología, en particular la implementación de sistemas de videovigilancia como instrumento esencial para ofrecer seguridad a los ciudadanos. Desde entonces, aquella no ha dejado de crecer; como señala Goold (2010) al describir la situación del Reino Unido, desde hace veinticinco años se ha observado un desarrollo exponencial del uso de videovigilancia.

A dicha circunstancia se le debe sumar el constante proceso de evolución en el que están inmersos los sistemas de videovigilancia, que hoy en día no solo permiten recopilar información fotográfica y sonora de determinados lugares y personas, sino que cuentan con una gran capacidad de almacenamiento y una amplísima gama de

\footnotetext{
${ }^{9}$ STC 341/1993 de 12 de noviembre.

${ }^{10}$ (Parejo, 2011, pp. 103 y ss.). Sobre el tema de la "sociedad del riesgo", puede verse el excelente trabajo de Ulrich (2000, pp. 9-20).
} 
posibilidades de compilación e interconexión de las bases de datos (big data) que cada día ofrecen nuevas aplicaciones (Arzoz, 2010, p. 21). En efecto, es indiscutible el vertiginoso desarrollo tecnológico que los sistemas de captación de imagen y sonido han tenido y seguirán teniendo. Han multiplicado de forma exponencial las posibilidades de manejar y conectar datos de los ciudadanos y, con ello, la capacidad de afectación restrictiva de los derechos y libertades; a la fecha, el cruce y el contraste de datos, su almacenamiento, tratamiento y distribución se pueden hacer con una capacidad y velocidad inimaginables hace muy poco tiempo atrás. Estos avances determinan que la videovigilancia se convierta cada día más en un mecanismo de valor extraordinario para garantizar la seguridad ciudadana, eso sí, con su correlativo riesgo creciente para los derechos y las libertades de los ciudadanos.

\section{El uso de los sistemas de videovigilancia por las Fuerzas y Cuerpos de Seguridad}

\section{El principio de legalidad}

Los medios de grabación de imágenes y de sonidos fueron utilizados por las Fuerzas y Cuerpos de Seguridad españoles incluso con anterioridad a la existencia de una regulación que contemplase la forma y los supuestos en los que debían ser empleados dichos medios. Pero hoy en día resultaría cuando menos ingenuo pretender que en una sociedad democrática moderna, los cuerpos y Fuerzas de Seguridad se vieran limitados a la utilización de técnicas y medios arcaicos o inoperantes ${ }^{11}$. No cabe duda de que el uso lícito de estas nuevas técnicas, en particular, los sistemas de grabación de imágenes y sonidos, y su posterior tratamiento incrementan sustancialmente el nivel de protección de los bienes y de las libertades de las personas. No obstante, como el Consejo General del Poder Judicial apunta, no es posible olvidar que "La vigilancia y captación por medios audiovisuales de imágenes y sonidos personales, aunque se produzca en lugares públicos, no es una actividad neutra, carente de efectos sobre los derechos y libertades fundamentales de los ciudadanos [en cuanto] en los lugares públicos se desarrollan también ámbitos de

\footnotetext{
${ }^{11}$ Sentencia de la Audiencia Provincial de Bilbao (sección 1a) de fecha 10 de enero de 1995
} 
privacidad merecedores de protección, materializados en conversaciones íntimas o en actos reveladores de las más íntimas convicciones y sentimientos individuales"12.

Resulta preciso, por tanto, que cuando las Fuerzas y Cuerpos de Seguridad utilicen esta clase de tecnología, actúen sujetos a los mandatos normativos que garantizan en todo momento, no solo la eficacia de los resultados obtenidos, sino que no se produzca una vulneración de los derechos fundamentales, debiendo ajustar a la habilitación legal existente. Solo de esta manera se puede hablar de un absoluto respeto a la $\mathrm{CE}$ y al resto del ordenamiento, dando pleno cumplimiento al mandato constitucional recogido en el artículo $9.1^{13}$ y al artículo 5.1 de la Ley Orgánica 2/1986, de 13 de marzo de Fuerzas y Cuerpos de Seguridad, que exigen la sujeción de la actuación de dichas fuerzas al ordenamiento jurídico ${ }^{14}$.

Recordemos que el requisito de legalidad en la actuación de las Fuerzas y Cuerpos de Seguridad del Estado es una exigencia que no solo concreta la $\mathrm{CE}$, sino que también es recogido expresamente en el Convenio Europeo de Derechos Humanos que, concretamente en su artículo 8.2, obliga a que toda injerencia de la autoridad pública en la "vida privada" de las personas se encuentre prevista en una ley que constituya, a su vez, una medida que sea necesaria para la seguridad social, la seguridad pública, el bienestar económico del país, la salud o la moral o la protección de los derechos y de las libertades de los demás en toda sociedad democrática. Por lo demás, se debe indicar que el Convenio citado obliga a que las intervenciones de los poderes públicos en ese ámbito cuenten con una regulación suficiente, en términos claros y precisos, de las condiciones en que puede

\footnotetext{
${ }^{12}$ En el Informe emitido por el citado órgano al Proyecto de LOV.

${ }^{13}$ Dicho artículo dispone: "Los ciudadanos y los poderes públicos están sujetos a la Constitución y al resto del ordenamiento jurídico.” Y en el apartado 3 señala "La Constitución garantiza el principio de legalidad...".

${ }^{14}$ Señala el precepto que "Son principios básicos de actuación de los miembros de las Fuerzas y Cuerpos de Seguridad los siguientes: 1. Adecuación al ordenamiento jurídico, especialmente:

a) Ejercer su función con absoluto respeto a la Constitución y el resto del ordenamiento jurídico.

b) Actuar, en el cumplimiento de sus funciones, con absoluta neutralidad política e imparcialidad y, en consecuencia, sin discriminación alguna por razón de raza, religión u opinión.

c) Actuar con integridad y dignidad. En particular, deberán abstenerse de todo acto de corrupción y oponerse a él resueltamente.

d) Sujetarse en su actuación profesional a los principios de jerarquía y subordinación. En ningún caso la obediencia debida podrá amparar órdenes que entrañen la ejecución de actos que manifiestamente constituyan delito o sean contrarios a la Constitución o a las Leyes.

e) Colaborar con la Administración de Justicia y auxiliarla en los términos establecidos en la Ley".
} 
producirse tal intervención ${ }^{15}$. Para el Tribunal Europeo de Derechos Humanos -en adelante TEDH-, la noción de "vida privada" es amplia, no susceptible de una definición exhaustiva, que abarca la integridad física y moral de la persona y, por tanto, engloba múltiples aspectos de la identidad de un individuo, dentro de las cuales se comprende, lógicamente, la grabación de imágenes de video. Pues bien, como ha reconocido el TEDH, la captación de las imágenes de una persona por videocámaras constituye, sin lugar a dudas, una injerencia en su vida privada, salvo que estas sean obtenidas con fundamento en leyes que legitimen tal actuación ${ }^{16}$. De ahí la necesidad de contar con una regulación clara y precisa.

También el Tribunal Constitucional Español ha subrayado que la videovigilancia es un medio particularmente invasivo y que por ello resultan necesarias tanto la concurrencia de condiciones que legitimen los tratamientos como la definición de los principios y de las garantías que se deben aplicar ${ }^{17}$. El mismo Tribunal ha destacado también la dimensión positiva de los derechos a la intimidad, que hoy exige su protección no solo frente a las injerencias tradicionales, sino también frente a los riesgos que pueden surgir en una sociedad tecnológicamente avanzada ${ }^{18}$.

\section{La habilitación normativa para el uso de sistemas de videovigilancia}

En España, la habilitación legal para que los Cuerpos y Fuerzas de Seguridad puedan utilizar estos sistemas de videovigilancia se encuentra recogida en la LOPSC, concretamente en el artículo 22, que dispone expresamente lo siguiente:

La autoridad gubernativa y, en su caso, las Fuerzas y Cuerpos de Seguridad podrán proceder a la grabación de personas, lugares u objetos mediante cámaras de videovigilancia fijas o móviles legalmente autorizadas, de acuerdo con la legislación vigente en la materia.

En el momento de acabar esta líneas, aquella regulación vigente en la materia es la ya mencionada Ley Orgánica 4/1997, de 4 de agosto, reguladora de la utilización

\footnotetext{
${ }^{15}$ Entre muchas otras, Sentencias del TEDH asunto Klass (1978\2), asunto Schenk (1988\4), asunto Malone (1984\1).

${ }^{16}$ Sentencia del TEDH, en asunto De La Flor Cabrera c. España, de 27 de mayo de 2014.

${ }^{17}$ STC 29/2013 de 11 de febrero.

${ }^{18}$ STC $119 / 2001$ de 24 de mayo (FJ 5) y STC 16/2004 de 23 de febrero (FJ 3).
} 
de videocámaras por las Fuerzas y Cuerpos de Seguridad en lugares públicos -en adelante, $\mathrm{LOV}^{19}$-, texto legal de rango orgánico porque su contenido incide en la regulación de las condiciones básicas del ejercicio de determinados derechos fundamentales, como el derecho a la propia imagen, el derecho de reunión o el derecho a la protección de datos o a la intimidad.

La LOV constituye, pues, el marco legal aplicable a la utilización de los sistemas de grabación de imágenes y sonidos por las Fuerzas y Cuerpos de Seguridad en el cumplimiento de las competencias encomendadas por el artículo 104 de la CE respecto de la protección del libre ejercicio de los derechos y libertades, y garantizar la seguridad ciudadana. Con posterioridad fue aprobado el Real Decreto 596/1999, de 16 de abril, por el que se aprueba el Reglamento de desarrollo y ejecución de la Ley Orgánica 4/1997, de 4 de agosto, por la que se regula la utilización de videocámaras por las Fuerzas y Cuerpos de Seguridad en lugares públicos -en adelante RDLOV-, reglamento que vino a establecer el desarrollo normativo de las garantías contenidas en la LOV. Es entonces por medio de la promulgación y la entrada en vigor de estas dos regulaciones como han sido introducidas las garantías precisas para que el poder público pueda intervenir en el ejercicio de los derechos y las libertades reconocidos en la $\mathrm{CE}$ en el marco jurídico establecido, de tal forma que no pueda hablarse de una injerencia en la vida privada de las personas.

\section{Análisis de la LOV}

\section{Objeto de la LOV}

La LOV y su reglamento de desarrollo (Real Decreto 596/1999, de 16 de abril) permiten la utilización de las videocámaras por las Fuerzas y Cuerpos de Seguridad, regulando los procedimientos para la instalación de aquellas (fijas o móviles) e introduciendo las correspondientes garantías para que el ejercicio de los derechos y libertades reconocidos en la $\mathrm{CE}$ sea máximo y no se vea perturbado con un exceso de celo en la defensa de la seguridad pública. Con tal finalidad, establece un régimen estricto de autorización administrativa previa y crea las Comisiones

${ }^{19}$ Como señala la propia norma, su aprobación corresponde al Estado en el ejercicio de la competencia que le atribuye la Constitución (artículo 149.1.29a) en materia de seguridad pública, sin perjuicio de las competencias que correspondan a las comunidades autónomas en esta materia de acuerdo con lo que dispongan sus propios Estatutos de Autonomía. 
de Garantía de Videovigilancia como órganos independientes y especializados a los que atribuye el papel de velar por la utilización adecuada de aquellos sistemas. $\mathrm{El}$ artículo primero de la citada norma dispone que la finalidad de la LOV es:

(...) contribuir a asegurar la convivencia ciudadana, la erradicación de la violencia y la utilización pacífica de las vías y espacios públicos, así como de prevenir la comisión de delitos, faltas e infracciones relacionados con la seguridad pública.

Junto con esta finalidad también establece, específicamente,

(...) el régimen de garantías de los derechos fundamentales y libertades públicas de los ciudadanos que habrá de respetarse ineludiblemente en las sucesivas fases de autorización, grabación y uso de las imágenes y sonidos obtenidos conjuntamente por las videocámaras. (Art. 1).

Consecuentemente, de acuerdo con la LOV, solo es válida y legal la captación, la reproducción y el tratamiento de imágenes y sonidos si se realizan en los términos previstos en esta, lo que determina también que no se consideren intromisiones ilegítimas en el derecho al honor, a la intimidad personal y familiar y a la propia imagen, según lo establecido en el artículo 2.2 de la Ley Orgánica 1/1982, de 5 de mayo, que señala:

"No se apreciará la existencia de intromisión ilegítima en el ámbito protegido cuando estuviere expresamente autorizada por Ley o cuando el titular del derecho hubiere otorgado al efecto su consentimiento expreso".

En todo caso, es preciso señalar que la propia LOV solo resulta aplicable cuando se utilizan sistemas de videocámaras (fijas y/o móviles) en lugares públicos, convirtiéndose dicho instrumento en un elemento esencial para establecer el ámbito de aplicación de la norma. Sin embargo, basta señalar que la LOV no contiene una definición de aquellos elementos técnicos, pero se aproxima a estos desde una concepción amplia al señalar que "las referencias contenidas en esta Ley a videocámaras, cámaras fijas y cámaras móviles se entenderán hechas a cualquier medio 
técnico análogo y, en general, a cualquier sistema que permita las grabaciones previstas en esta Ley".

De la interpretación expuesta es posible deducir que se encuentran incluidas dentro de aquellos conceptos nuevos sistemas o medios tecnológicos. De esta forma se evita que la norma pueda quedar obsoleta ante la aparición de otros sistemas que cumplan la misma finalidad. Así, por ejemplo, se pueden considerar incluidas las grabaciones efectuadas mediante un teléfono móvil o cualquier otro aparato capaz de captar imagen y/o sonido, como los drones.

\section{Ámbito de aplicación de la LOV}

\section{1. Ámbito comprendido: lugar público}

Como es sabido, la captación y/o el tratamiento de imágenes con fines de vigilancia es una práctica muy extendida en nuestra sociedad. En algún caso, la finalidad perseguida es proteger la seguridad y el orden público en las vías públicas con carácter esencialmente preventivo, constituyendo su objetivo principal evitar los peligros y riesgos que se pueden cernir sobre los bienes y derechos constitucionalmente protegidos. Por tanto, la captación y el tratamiento de los datos, dentro de los cuales se engloban las tareas de sistematización y evaluación de las informaciones obtenidas, en lo que la LOV denomina "lugares públicos", se transforma en una actividad que corresponde, en exclusiva, a las Fuerzas y Cuerpos de Seguridad, en cuanto les permiten a estas cumplir eficazmente las funciones reconocidas de prevención. Así lo recoge el artículo 1.o de la LOV, que dispone:

La presente Ley regula la utilización por las Fuerzas y Cuerpos de Seguridad de videocámaras para grabar imágenes y sonidos en lugares públicos abiertos o cerrados, y su posterior tratamiento, a fin de contribuir a asegurar la convivencia ciudadana, la erradicación de la violencia y la utilización pacífica de las vías y los espacios públicos, así como de prevenir la comisión de delitos, faltas e infracciones relacionados con la seguridad pública.

Este precepto se debe poner en relación con lo dispuesto en el artículo 3 e) de la Ley Orgánica 15/1999, de 13 de diciembre, de protección de los datos de carácter personal -en adelante, LOPD-, que señala: 
"Se regirán por sus disposiciones específicas y por lo especialmente previsto, en su caso, por esta LOPD los siguientes tratamientos de datos personales:

e) Los procedentes de las imágenes y sonidos obtenidos mediante la utilización de videocámaras por las Fuerzas y Cuerpos de Seguridad, de conformidad con la legislación sobre la materia."

Pues bien, en virtud de lo recogido en ambas disposiciones, se entiende que la instalación de videocámaras en lugares públicos abierto o cerrados es competencia exclusiva de las Fuerzas y Cuerpos de Seguridad, siempre que aquella actividad contribuya a asegurar la convivencia ciudadana, la erradicación de la violencia y la utilización pacífica de las vías y los espacios públicos, así como la prevención de la comisión de delitos, faltas e infracciones relacionados con la seguridad pública. La legitimación para la realización del tratamiento de dichas imágenes se recoge en la LOV, texto que, además, regula los criterios para instalar las cámaras y los derechos de los interesados, sin perjuicio de la aplicación supletoria de la LOPD en determinados aspectos ${ }^{20}$.

Ahora bien, llegados a este punto deberíamos preguntarnos a qué se refieren los conceptos de "lugar público" o "espacios abiertos al público" que utiliza la LOV. La citada norma legal no contiene una definición que permita acotar dicho concepto, por tanto, el ámbito de aplicación de la Ley tan solo menciona aquellos términos. Siguiendo en este punto a Arzoz (2010, p. 53), el aspecto más relevante para que la citada LOV sea aplicada es la apertura al público y la accesibilidad general, no la titularidad del espacio. Sin embargo, existe un supuesto que la LOV excluye de su ámbito de aplicación a pesar de ser un lugar público: se trata de la instalación y el uso de videocámaras y cualquier otro medio de captación y reproducción de imágenes, que tenga por finalidad controlar, regular, vigilar y aplicar la disciplina del tráfico. En estos casos, la normativa aplicable es el Real Decreto Legislativo 6/2015, de 30 de octubre, por el que se aprueba el texto refundido de la Ley sobre Tráfico, Circulación de Vehículos a Motor y Seguridad Vial, y demás normativa que lo desarrolle y corresponde a la autoridad encargada de esta materia realizar tal función. No obstante, se debe aclarar que estas imágenes y estos sonidos se sujetan con carácter supletorio a la LOV, a la LOPD y a la Ley Orgánica 1/1982,

\footnotetext{
${ }^{20}$ Véase al respecto la Resolución R/02712/2013 o R/02787/2013, entre muchas otras
} 
de 5 de mayo ${ }^{21}$. A pesar de la exclusión indicada, las cámaras puestas con esta finalidad pueden ser utilizadas en el marco de la LOV por las Fuerzas y Cuerpos de Seguridad, siempre que se tramiten todas las autorizaciones previstas en esta.

Además del supuesto mencionado de exclusión, la LOV concreta otros supuestos a los que se deben sumar los lugares que la LOPSC excluye y que, si bien obliga a que en estos se adopten medidas de seguridad con el fin de prevenir actuaciones que puedan poner en peligro la seguridad, dicha obligación no está referida a las Fuerzas y Cuerpos de Seguridad. Veamos ambos supuestos de exclusión.

\section{2. Ámbito excluido de la LOV}

Como hemos visto, la delimitación del ámbito de aplicación antes expuesto de la LOV (lugares públicos) se debe diferenciar de la captación y el tratamiento de imágenes y sonidos por medio de sistemas de videocámaras en lugares privados. En este último caso, la finalidad de estos sistemas de videovigilancia es ofrecer protección a determinados lugares que no se consideran lugares públicos, como viviendas, oficinas, empresas, espectáculos, bancos, salas de juego, etc. No se trata, como hemos dicho, de lugares públicos, aunque ellos se encuentren abiertos al público. En la medida en que con estos sistemas se capten imágenes y sonidos que permitan identificar directa o indirectamente a personas físicas, tales imágenes y sonidos son considerados datos de carácter personal y como tal, sujeto a lo dispuesto en la LOPD, en el Real Decreto 1720/2007, de 21 de diciembre, por el que se aprueba el Reglamento de Desarrollo de la LOPD -en adelante, RDLOPD- y más concretamente, a la Instrucción 1/2006, de 8 de noviembre, de la Agencia Española de Protección de Datos, sobre el tratamiento de datos personales con fines de vigilancia por medio de sistemas de cámaras o videocámaras -en adelante, Instrucción 1/2006, de 8 de noviembre-. En estos lugares, también es importante destacar, en principio, que los sujetos autorizados para realizar aquel servicio de videovigilancia son los que forman parte de la denominada "Seguridad Privada", que se rigen por la Ley 5/2014, de 4 de abril, de Seguridad Privada y al Real Decreto 2364/1994, por el que se aprueba el Reglamento de Seguridad Privada.

En definitiva, si la grabación, captación, transmisión, conservación y el almacenamiento de imágenes/sonidos se realiza en un ámbito que no es lugar público,

\footnotetext{
${ }^{21} \mathrm{RLOV}$, disposición adicional octava.
} 
dichas imágenes y sonidos se sujetan a la LOPDen cuanto dato de carácter personal y quedan excluidos de la LOV.

Teniendo en cuenta lo anterior, la propia LOV excluye directamente de su ámbito de aplicación a los siguientes:

- La utilización de los sistemas de videovigilancia para captar imágenes o sonidos en el interior de las viviendas y sus vestíbulos por cuanto se trata de lugares privados. Solo se permite captarlos por las Fuerzas y Cuerpos de Seguridad si existe consentimiento del titular de la vivienda o autorización judicial (art. 1.1 y 6.3).

- Tampoco se aplica la LOV, incluso en este caso, en las vías y en los espacios públicos cuando se afecte de forma directa y grave la intimidad de las personas o cuando se utilice para grabar conversaciones de naturaleza estrictamente privada. En este caso, la norma obliga a que las imágenes y los sonidos captados de este tipo sean destruidos inmediatamente por quien tenga la responsabilidad de su custodia (art. 6.3).

- Igualmente, se excluyen las instalaciones fijas de videocámaras en los inmuebles que pertenecen a las Fuerzas Armadas y a las Fuerzas y Cuerpos de Seguridad siempre que estas se dediquen exclusivamente a garantizar la seguridad y protección interior, y no de lugares públicos. En este caso se trata de un lugar privado, y las imágenes captadas son consideradas datos de carácter personal, sujetas a la LOPD y a las demás normas de desarrollo ${ }^{22}$.

- Las captaciones de imágenes y sonidos mediante videocámaras de las unidades de Policía Judicial cuando desempeñen funciones de policía judicial en sentido estricto. Tales captaciones se sujetan a la Ley de Enjuiciamiento Criminal y normativa específica ${ }^{23}$, y a la LOPD.

Por otra parte, como hemos mencionado, existen determinados lugares que presentan ciertas peculiaridades por el tipo de actividades que en ellos se desarrollan y en donde el concepto de "lugar público" se puede confundir con el de "lugar privado" porque muchos de ellos son establecimientos abiertos al público o donde se realizan actividades importantes desde el punto de vista económico, donde también se corresponde garantizar la seguridad, prevenir la comisión de delitos, faltas e infracciones para mantener el orden público. Se trata de los establecimientos o

\footnotetext{
${ }^{22} \mathrm{RLOV}$, artículo $2 .^{\circ}$, apartados 1 y 3.

${ }^{23} \mathrm{RLOV}$, artículo $2 .^{\circ}$, apartados 1 y 3 .
} 
instalaciones como los bancos, los casinos o las salas de bingo, establecimientos comerciales, etc. En todos estos casos, la LOPSC excluye su aplicación al establecer:

Reglamentariamente, en desarrollo de lo dispuesto en esta Ley, en la legislación de seguridad privada, en la de infraestructuras críticas o en otra normativa sectorial, podrá establecerse la necesidad de adoptar medidas de seguridad en establecimientos e instalaciones industriales, comerciales y de servicios, así como en las infraestructuras críticas, con la finalidad de prevenir la comisión de actos delictivos o infracciones administrativas, o cuando generen riesgos directos para terceros o sean especialmente vulnerables. (Art.26).

No es posible tatar todos los supuestos, por eso solo mencionaremos algunos que pueden resultar ilustrativos junto con la normativa que resulta de aplicación. En todos estos casos, la LOV no resulta aplicable, salvo en algún supuesto con carácter supletorio. Veamos algunos de ellos.

- Lo bancos, las cajas de ahorro y demás entidades de crédito que, en razón a los especiales riesgos inherentes a su actividad, se obligan a la instalación de medios de videovigilancia por cuanto se custodian fondos o valores, con plena aplicación del principio de proporcionalidad. En este caso, el uso de estos sistemas se sujeta a la LOPSC, a la Ley 5/2014, de 4 de abril, de Seguridad Privada y al Real Decreto 2364/1994, por el que se aprueba el Reglamento de Seguridad Privada y supletoriamente la LOPD. En toda esta normativa se obliga a que:

- se instalen equipos o sistemas de captación y registro con capacidad para obtener las imágenes de los autores de delitos contra las personas y contra la propiedad en los establecimientos y oficinas que permitan la posterior identificación de aquellos;

- los sistemas funcionen durante el horario de atención al público sin que sea precisa la intervención inmediata de los empleados de la entidad;

- los soportes destinados a la grabación de imágenes estén protegidos contra el robo, correspondiendo a la entidad de ahorro o de crédito conservar con las imágenes grabadas durante al menos quince días contados desde la fecha de la grabación. Durante dicho plazo, las citadas grabaciones deben estar a disposición, exclusivamente, de las autoridades judiciales y de las Fuerzas y Cuerpos de Seguridad. Una vez 
trascurrido el plazo legal de conservación, corresponde inmediatamente eliminar el contenido grabado, salvo que las autoridades judiciales o las Fuerzas y Cuerpos de Seguridad competentes establezcan fundadamente lo contrario;

- el contenido de los soportes debe ser preservado, y las imágenes grabadas solo pueden ser utilizadas como medio de identificación de los autores de delitos contra las personas y contra la propiedad.

- Los casinos o las salas de bingo cuentan también con un régimen específico contenido en la Instrucción 2/1996, de 1 de marzo, de la Agencia Española de Protección de Datos sobre Ficheros Automatizados, cuya finalidad es controlar el acceso a los recintos mencionados. En la citada instrucción se obliga al responsable del fichero -identificado con la sociedad explotadora del casino de juegos o la empresa titular de la sala de bingo- a que asuma el cumplimiento de todas las obligaciones establecidas en la LOPD. Por esta razón, solo se deben recoger datos de control de acceso, ofrecer "información" por medio de los carteles correspondientes y no utilizar las grabaciones con otros fines. Tampoco pueden ser cedidos fuera de los casos expresamente establecidos por la ley, salvo que exista un consentimiento claro del afectado.

- Los espacios públicos de uso privado, como establecimientos comerciales, restaurantes, lugares de ocio, etc. Se trata de lugares privados abiertos al público, por lo que se sujetan, en su totalidad, a la LOPD y normativa de desarrollo. La exigencia general es que la instalación de videovigilancia se sujete a una ponderación de los derechos y se cumpla estrictamente con el principio de proporcionalidad.

- La instalación de cámaras de videovigilancia en un centro escolar con el fin de controlar conductas que puedan afectar a la seguridad. En este caso, nos encontramos ante un lugar privado de uso público al que resulta aplicable la LOPD y demás normativa. En todo caso, se exige que el sistema instalado sea proporcional en relación con la infracción que se pretenda evitar y, en ningún caso debe suponer el medio inicial para llevar a cabo funciones de vigilancia.

- La instalación de sistemas de videovigilancia destinados a proteger espacios privados, pero que captan imágenes de la vía pública. Estos sistemas se pueden instalar siempre que el responsable demuestre que la captación de 
aquellas imágenes en las vías públicas bien resulta imprescindible para la finalidad de vigilancia pretendida, bien resulta imposible evitar su captación por razón de la ubicación de aquellas. En dicha hipótesis, el responsable debe adecuar el uso de las instalaciones de modo tal que el impacto en los derechos de los viandantes sea el mínimo posible ${ }^{24}$. En todo caso, es preciso destacar que las captaciones de imágenes realizadas por los sujetos privados que desarrollan actividades de videovigilancia, como las empresas dedicadas a seguridad, pueden ser cedidas a las Fuerzas y Cuerpos de Seguridad de acuerdo con lo dispuesto por la Ley 5/2014, de 4 de abril, de Seguridad Privada, que en su artículo 15 señala el siguiente tenor:

1. Se autorizan las cesiones de datos que se consideren necesarias para contribuir a la salvaguarda de la seguridad ciudadana, así como el acceso por parte de las Fuerzas y Cuerpos de Seguridad a los sistemas instalados por las empresas de seguridad privada, que permitan la comprobación de las informaciones en tiempo real cuando ello sea necesario para la prevención de un peligro real para la seguridad pública o para la represión de infracciones penales...

3. La comunicación de buena fe de información a las Fuerzas y Cuerpos de Seguridad por las entidades y el personal de seguridad privada no constituirá vulneración de las restricciones sobre divulgación de información impuestas por vía contractual o por cualquier disposición legal, reglamentaria o administrativa, cuando ello sea necesario para la prevención de un peligro real para la seguridad pública o para la represión de infracciones penales.

- Un supuesto peculiar son los espectáculos deportivos. El artículo 27.4 de la LOPSC señala:

Los espectáculos deportivos quedarán, en todo caso, sujetos a las medidas de prevención de la violencia dispuestas en la legislación específica contra la violencia, el racismo, la xenofobia y la intolerancia en el deporte.

Violencia, racismo, xenofobia e intolerancia en el deporte, norma que permite el uso de los sistemas de videovigilancia en los acontecimientos deportivos con la finalidad de "mantener la seguridad ciudadana y el orden público en

${ }^{24}$ Así lo permite el artículo 4.3 de la Instrucción 1/2006 de la AEPD 
los espectáculos deportivos con ocasión de la celebración de competiciones y espectáculos deportivos.

Para conseguir dicho fin, obliga a las personas organizadoras de las competiciones y espectáculos deportivos que la Comisión Estatal contra la Violencia, el Racismo, la Xenofobia y la Intolerancia en el Deporte determine instalar circuitos cerrados de televisión para grabar el acceso y el aforo completo del recinto deportivo, grabación que también puede incluir los aledaños en los que se puedan producir aglomeraciones de público ${ }^{25}$. En estos casos se obliga a que los organizadores adopten las medidas necesarias para garantizar el buen estado de conservación y el correcto funcionamiento de las cámaras, así como a instalar, si se considera necesario por la autoridad gubernativa, sistemas de videovigilancia en competiciones o encuentros específicos. En todos estos casos, es necesario realizar una ponderación de la proporcionalidad de la medida adoptada con el fin perseguido.

Igualmente, es preciso indicar que la citada disposición legal determina que la instalación de los dispositivos de videovigilancia a los que se refieren los artículos 4 -Consumo y venta de bebidas alcohólicas y de otro tipo de productos- y 12 -Medidas especiales en competiciones o encuentros especificos-, así como el tratamiento de las imágenes resultantes de la utilización de dichos dispositivos se encuentran sometidos a lo dispuesto en la LOV. Existe también la obligación de ceder las imágenes captadas a las Fuerzas y Cuerpos de Seguridad o a las autoridades competentes si se aprecia la existencia de alguna conducta punible o sancionable a fin de que se incorporen al procedimiento judicial o administrativo correspondiente ${ }^{26}$.

\section{El principio de proporcionalidad y la instalación de videovigilancia. Su ponderación}

${ }^{25}$ El artículo 20 de la norma legal citada dispone que la Comisión Estatal es un órgano colegiado encargado de la formulación y realización de políticas activas contra la violencia, la intolerancia y la evitación de las prácticas racistas y xenófobas en el deporte. Se trata de un órgano integrado por representantes de la Administración General del Estado, de las comunidades autónomas y corporaciones locales, de las federaciones deportivas españolas o ligas profesionales, asociaciones de deportistas y por personas de reconocido prestigio en el ámbito del deporte y la seguridad, la lucha contra la violencia, el racismo y la intolerancia, así como la defensa de los valores éticos que encarna el deporte.

${ }^{26}$ Un estudio sobre este tema Arzoz (2010, pp. 61 y ss.). 
Como tendremos ocasión de estudiar, la instalación de cámaras -sean móviles o fijas- por las Fuerzas y Cuerpos de Seguridad en los lugares públicos se encuentra sujeta a un riguroso procedimiento de autorización previa y de control. En dicho proceso se debe valorar obligatoriamente que se cumple con el principio de proporcionalidad en su doble versión de idoneidad e intervención mínima. Se trata de un principio que legitima la actuación y que debe ser valorado por todos los órganos que intervienen y, en especial, por el propio promotor (art 6).

El citado principio de proporcionalidad exige que la medida adoptada sea idónea para alcanzar el fin perseguido con ella, que sea necesaria e imprescindible para la finalidad que se persigue y que no existan otras medidas más moderadas o menos agresivas para la consecución de tal propósito con igual eficacia. Además de cumplir estos requisitos, se exige que la medida adoptada de instalar videovigilancia en lugares públicos sea proporcionada en sentido estricto, es decir, ponderada y/o equilibrada, por derivarse de ella más beneficios o ventajas para el interés general que perjuicios sobre otros bienes o valores en conflicto. Para verificar que una medida restrictiva de un derecho fundamental supera el juicio de proporcionalidad, es necesario constatar si cumple con los siguientes juicios ${ }^{27}$ :

- Juicio de idoneidad. La medida adoptada debe ser susceptible de conseguir el objetivo propuesto. En nuestro caso, la LOV estima que solo se puede utilizar la videocámara cuando resulte adecuado, en una situación concreta, para el mantenimiento de la seguridad ciudadana, de conformidad con lo dispuesto en esta Ley.

- Juicio de necesidad. Se debe constatar que no existe otra medida más moderada para la consecución del tal propósito con igual eficacia. Es preciso, por tanto, que los órganos competentes comparen las medidas restrictivas aplicables que sean suficientes para satisfacer el fin perseguido y que, en último término, se escoja aquella menos lesiva para los derechos de los ciudadanos. Con este principio se debe valorar que no existan otros medios menos gravosos para obtener la misma finalidad. De ahí que no sería legítimo, de acuerdo con este principio, la proliferación de cámaras para controlar a la generalidad sin que exista un juicio fundado sobre la necesidad de su instalación con la finalidad precisa, en todo caso, de prevenir

${ }^{27}$ SSTC 37/1989, de 15 de febrero; SSTC 7/1994, de 17 de enero y SSTC 207/1996, de 16 de diciembre, entre otras. 
delitos o alteraciones del orden público, de ahí que solo se permita que se comprenda las imágenes que sean estrictamente necesarias (AEPD).

- Juicio de intervención mínima. Se debe ponderar, en cada caso, entre la finalidad pretendida y la posible afectación por la utilización de la videocámara al derecho al honor, a la propia imagen y a la intimidad de las personas.

- Juicio estricto de proporcionalidad. Supone que la medida adoptada es equilibrada en cuanto de ella se derivan más beneficios o ventajas para el interés general que perjuicios sobre otros bienes o valores. De ahí que solo se considere válido el uso de los sistemas de videocámaras si existe un razonable peligro claro, inminente, y grave para la seguridad ciudadana si se trata de cámaras fijas o un peligro concreto, si se trata de las videocámaras móviles.

La determinación de que los sistemas de videovigilancia han respetado estos juicios será objeto de control tanto por la Administración como por el Poder Judicial. Así lo exige la LOV, que permite que contra todas las resoluciones dictadas en aplicación de lo previsto en la citada Ley se puedan interponer los recursos pertinentes en la vía administrativa, así como contencioso-administrativo, por lo que cualquier persona que considere vulnerados sus derechos puede acudir al ámbito judicial para que realice un control de las medidas adoptadas en especial su proporcionalidad. También la LOV permite que se puedan interponer los recursos previstos en el artículo 53.2 de la Constitución, en los términos legalmente establecidos. Recordemos que el precepto citado dispone:

2. Cualquier ciudadano podrá recabar la tutela de las libertades y derechos reconocidos en el artículo 14 y la Sección primera del Capítulo segundo ante los Tribunales ordinarios por un procedimiento basado en los principios de preferencia y sumariedad y, en su caso, a través del recurso de amparo ante el Tribunal Constitucional.

\section{Las garantías que la LOV establece para permitir el uso de los sistemas de videovigilancia por las Fuerzas y Cuerpos de Seguridad}

Recordemos que de acuerdo con la LOV, para que las Fuerzas y Cuerpos de Seguridad puedan utilizar sistemas de videovigilancia se requiere que tales sistemas sean estrictamente respetuosos con los derechos y las libertades de los ciudadanos. 
Para evitar cualquier vulneración, se articula por la normativa un importante régimen de garantías, dentro del cual se encuentra, por un lado, la actuación de las Comisiones de Garantías de Videovigilancia y, por otro, el sometimiento de las instalaciones de videocámaras fijas y móviles a un régimen de autorización administrativa previa y a posteriori muy rigurosa. Veamos cada una de ellas

\section{- Las Comisiones de Garantía de Videovigilancia}

Las denominadas Comisiones de Garantías de Videovigilancia -en adelante, las Comisiones- son órganos colegiados de ámbito territorial autonómico y de carácter consultivo, dotados de independencia de la autoridad administrativa que otorgan las autorizaciones de instalación de sistemas de videovigilancia en lugares públicos. De La Iglesia, las define como "un órgano colegiado de garantías, independiente y técnico, que actúa en el ámbito territorial autonómico, compuesto mayoritariamente por juristas, cuya función es la protección de los derechos y libertades de los ciudadanos frente a la actividad de instalación y utilización de sistemas de videovigilancia en lugares públicos por los Cuerpos y Fuerzas de Seguridad ${ }^{28}$.

Las mencionadas Comisiones tienen como función principal emitir los informes que resultan necesarios para otorgar, a la autoridad habilitada al efecto, la autorización de instalación y uso de videocámaras fijas o móviles por las Fuerzas y Cuerpos de Seguridad (art.12 RD) ${ }^{29}$.

La existencia de estas Comisiones tiene por finalidad articular un equilibrio entre seguridad y derechos y libertades de los ciudadanos. AsÍ mismo, persigue velar porque el uso de los sistemas no se traduzca en un sacrificio excesivo y desproporcionado de aquellos. En definitiva, se trata de un órgano "atípico" que actúa preventivamente sobre la posible vulneración de los derechos fundamentales por los

\footnotetext{
${ }^{28}$ De La Iglesia (2007, p. 221)

${ }^{29}$ Baste señalar que algunas comunidades autónomas con competencias para la protección de personas y bienes y para el mantenimiento del orden público, en virtud de la disposición adicional primera de la LOV21, han fijado su normativa específica sobre las CGV, marcando algunas diferencias con el régimen general. En Cataluña, el Decreto 134/1999, aprueba el reglamento de la videovigilancia por parte de la Generalidad y de los policías locales de Cataluña (BOCG n.o 2892, 19 de mayo) y crea y detalla el régimen jurídico de la Comisión de Control de los Dispositivos de Videovigilancia de Cataluña. Por su parte, en el País Vasco el correspondiente desarrollo normativo se ha llevado a cabo por el Decreto 168/1998 (BOPV n.o 142, de 29 de julio) por el que se crea y regula la Comisión de Videovigilancia Libertades de la Comunidad Autónoma Vasca.
} 
riesgos generados por el desarrollo tecnológico, y cuya actuación es complementaria de los mecanismos jurisdiccionales ordinarios ${ }^{30}$.

Estos órganos se integran por el presidente, cargo que recae en el presidente del Tribunal Superior de Justicia en la Comunidad Autónoma correspondiente y, por cuatro vocales: el fiscal jefe del Tribunal Superior de Justicia en la Comunidad Autónoma correspondiente; un abogado del Estado designado por el director del Servicio Jurídico del Estado de entre los destinados en la localidad donde tenga su sede el Tribunal Superior de Justicia en la Comunidad Autónoma correspondiente; un representante de la Administración General del Estado; un alcalde representante de los municipios encuadrados en el ámbito de la correspondiente Comunidad Autónoma designado por la Asociación de municipios de ámbito autonómico con mayor implantación. Se completa su organización con un secretario que recae en la figura del secretario general de la Delegación del Gobierno en la Comunidad Autónoma correspondiente, que debe asistir a las reuniones con voz, pero sin voto. Es posible también que a las reuniones asistan, en calidad de asesores o expertos en materia de seguridad ciudadana, determinados sujetos designados por el delegado del Gobierno en la Comunidad Autónoma correspondiente, quienes pueden participar en las reuniones con voz, pero sin voto (art.13.2).

Las funciones de las Comisiones vienen establecidas en el reglamento, que las concreta en las siguientes:

- Emitir un informe preceptivo sobre las solicitudes de instalaciones fijas de videocámaras. En este caso, el informe tiene carácter vinculante en dos supuestos. En primer lugar, cuando la Comisión considere que la instalación supone una vulneración de los criterios establecidos en el artículo 4 de la $\mathrm{LOV}$, en el que se recogen los criterios de autorización que inmediatamente veremos. En segundo, cuando el informe sea favorable a la instalación, pero esta contenga condiciones, restricciones, limitaciones o prevenciones para un cumplimiento cabal de la normativa.

- Recabar en cualquier momento a las Fuerzas y Cuerpos de Seguridad el soporte físico de las grabaciones efectuadas por videocámaras móviles para emitir el informe correspondiente.

\footnotetext{
${ }^{30}$ Sobre este tema, De La Iglesia (2007, p. 213).
} 
- Informar, a petición de las autoridades competentes, sobre la adecuación de cualquier registro de imagen y sonido obtenidos mediante videocámaras móviles a los principios enunciados en el artículo 6 de la LOV.

- Ordenar la destrucción de las grabaciones cuando, en el ejercicio de sus competencias, constaten el incumplimiento de los criterios y principios establecidos en la LOV.

- Requerir de las autoridades responsables la información necesaria para el ejercicio de sus funciones.

- Formular cuantas recomendaciones estimen oportunas en el ámbito de sus competencias.

Además de los supuestos mencionados, también resulta obligatorio contar con informe de las Comisiones de Garantías, cuando se dicten resoluciones de autorización de videocámaras móviles y cuando se realice un uso excepcional de estas de acuerdo con lo previsto en el apartado 2 del artículo 5 de la LOV. Igual información debe suministrar información, al menos con una periodicidad quincenal, sobre la utilización que se haga de videocámaras móviles (art. 5.3 LOV).

\section{- El régimen de autorización}

Dentro de las garantías que introduce la LOV en el uso de sistemas de grabación de imágenes y sonidos por parte de las Fuerzas y Cuerpos de Seguridad en lugares públicos se encuentran, como ya hemos visto, la necesidad de contar con una previa autorización previa para la instalación de videocámaras, que en todos los casos debe cumplir con el principio de proporcionalidad en los términos analizados. Recordemos que, en ambos casos, si el informe es negativo o condicionante, tiene carácter vinculante.

Es preciso destacar que el régimen de autorización es distinto de acuerdo con la LOV si la cámara que se persigue instalar es fija o móvil, si bien, es posible utilizar ambos tipos de sistemas de videovigilancia simultáneamente si se considera necesario para el mejor cumplimiento de los fines perseguidos (art. 5.1). En todo caso, todas las autorizaciones otorgadas se deben incluir en un registro que debe llevar al efecto el delegado de Gobierno. La inscripción se efectúa de oficio y en ella, como mínimo, deben constar los datos referentes al titular de la autorización, su fecha, el plazo de vigencia, el ámbito genérico de grabación y el órgano encargado de la 
custodia, así como la inutilización o destrucción de las grabaciones. Analicemos ambos supuestos.

1. Procedimiento de instalación de cámara fija en lugar público por las Fuerzas y Cuerpos de Seguridad

Como hemos apuntado con anterioridad, cuando las Fuerzas y Cuerpos de Seguridad consideren necesario instalar una cámara fija en un lugar público, deben obtener la correspondiente autorización de instalación. A tal efecto, han de solicitar dicho título jurídico ante el delegado del Gobierno en la Comunidad Autónoma correspondiente $^{31}$, quien debe remitir la solicitud formulada -con carácter previo a su resolución-, a la Comisión de Garantía de Vigilancia para que emita un informe preceptivo que, en todo caso, es vinculante si es negativo o condicionante.

El plazo máximo que tiene el Delegado del Gobierno para resolver es de dos meses, contados a partir del día siguiente al de la presentación de la solicitud. Evidentemente, la resolución emitida debe estar motivada y fundada en el principio de proporcionalidad, y cumplir los siguientes criterios:

- Que se trate de asegurar la protección de los edificios e instalaciones públicas y sus accesos.

- Que se persiga salvaguardar las instalaciones útiles para la defensa nacional.

- Que tenga como objetivo constatar posibles infracciones a la seguridad ciudadana, y prevenir daños a las personas y bienes.

La resolución debe señalar también el lugar público concreto que es posible observar, es decir, la determinación genérica del ámbito físico susceptible de ser grabado, así como contener todas las limitaciones o condiciones de uso necesarias y, en particular, la prohibición de tomar sonidos, salvo cuando exista un riesgo concreto y preciso. Aquella debe establecer igualmente aspectos tales como la cualificación de las personas encargadas de la explotación del sistema de tratamiento de imágenes y sonidos; la precisión del tipo de cámara que se puede utilizar y las especificaciones técnicas de estas; las medidas por adoptar para garantizar el respeto

${ }^{31}$ De acuerdo con el artículo 3.2 del RD la solicitud debe contener a) la identificación del solicitante, b) los motivos que la justifican, c) la definición genérica del ámbito físico susceptible de ser grabado, d) la necesidad o no de grabar sonidos con sujeción a las limitaciones legalmente establecidas, e) la cualificación de las personas encargadas de la explotación del sistema de tratamiento de las imágenes y sonidos, f) el tipo de cámara y sus condiciones técnicas, y g) el tiempo en el que se pretendan efectuar las grabaciones. 
de las disposiciones legales; y la duración de la autorización que nunca puede superar el año, aunque esta pueda renovarse ${ }^{32}$.

La resolución pone fin a la vía administrativa, y contra esta es posible interponer potestativamente recurso de reposición o impugnarla directamente ante el orden jurisdiccional contencioso-administrativo. Si transcurrido el plazo para dictar resolución (dos meses) no se dicta la autorización, esta se debe entender denegada.

2. Procedimiento de instalación de cámara móvil en lugar público por las Fuerzas y Cuerpos de Seguridad

La solicitud de instalación de cámaras móviles debe ser dirigida al delegado del Gobierno o subdelegado de la Comunidad Autónoma, según el caso. Si quien tiene previsto utilizar la misma son los mandos operativos de las Fuerzas y Cuerpos de Seguridad del Estado, la solicitud se debe realizar por el conducto reglamentario; si, por el contrario, va a ser utilizada por la policía local, corresponde bien al alcalde, bien al concejal competente en materia de seguridad ciudadana realizar su solicitud. La petición se debe realizar y resolver en el plazo de un mes, transcurrido el cual sin que exista contestación se entiende desestimada. Si la resolución es positiva, se debe comunicar a la Comisión de Vigilancia dentro de las setenta y dos horas contadas desde su adopción, por cualquier medio telemático, informático o documental que acredite su recepción. La resolución del delegado del Gobierno pone fin a la vía administrativa, y contra esta cabe interponer potestativamente recurso de reposición o directamente recurrirla ante el orden jurisdiccional contencioso-administrativo. Las resoluciones del subdelegado, por su parte, son recurribles en alzada.

${ }^{32}$ Las solicitudes de renovación de las autorizaciones para las instalaciones fijas de videocámaras o para la utilización de las móviles se deben tramitar y resolver por el mismo procedimiento que el establecido para las autorizaciones iniciales, si bien su motivación se limitará a las razones que recomienden la renovación. Solo procede otorgarla cuando subsistan o se agraven las circunstancias que motivaron el otorgamiento inicial.

En todo caso, las solicitudes de renovación de las autorizaciones que se otorgaron por el plazo máximo de un año se deben formular con dos meses de antelación a su expiración. El resto de las solicitudes se debe solicitar con una antelación mínima de un mes a la de la fecha de vencimiento de su vigencia, y en caso de ser la autorización inicial por plazo inferior a un mes, con una antelación mínima a la mitad del tiempo autorizado.

Si no se formula la solicitud de renovación en los plazos señalados en el apartado anterior, habrá de tramitarse como una nueva autorización. 
Sea como sea, cuando se solicita autorización para instalar cámaras móviles es preciso diferenciar tres supuestos ${ }^{33}$ :

- Cuando la cámara móvil se utilice en un lugar donde ya existe autorización de instalación de una cámara fija. En este supuesto, la LOV autoriza el uso simultáneo de ambas cámaras y supedita la toma conjunta de imagen y sonido a la concurrencia de un peligro concreto y al cumplimiento del principio de proporcionalidad en los términos antes estudiados (arts. 5 y 6).

- Cuando la cámara móvil se utilice en los restantes lugares públicos, en cuyo caso la autorización que se debe otorgar por el máximo responsable provincial de las Fuerzas y Cuerpos de Seguridad, subdelegado del Gobierno de la provincia o delegado en caso de las comunidades uniprovinciales, quien debe atender a la naturaleza de los eventuales hechos susceptibles de filmación y valorar la medida de acuerdo con el principio de proporcionalidad. La resolución dictada en este caso debe ser motivada y ser puesta en conocimiento de la Comisión de Vigilancia en un plazo máximo de setenta y dos horas que, si emite un informe negativo, corresponde a la autoridad encargada de la custodia de la grabación proceder a su inmediata destrucción.

- Cuando existan supuestos “excepcionales”, en los que se produzca una "urgencia máxima" o "la imposibilidad" de obtener a tiempo la autorización indicada en razón del momento de producción de los hechos o de las circunstancias concurrentes, las autoridades competentes directamente pueden obtener imágenes y sonidos con las videocámaras móviles.En las veinticuatro hora posteriores, las grabaciones se deben remitir al delegado o al subdelegado, quien debe emitir, ineludiblemente, en las veinticuatro horas siguientes, un informe motivado al respecto. Al igual que el supuesto anterior, en el plazo máximo de setenta y dos horas desde que se realizó la grabación se debe poner en conocimiento de la Comisión de Vigilancia, junto con el aludido informe motivado que puede requerir, si lo estima oportuno, la entrega del soporte físico original y emitir el correspondiente informe. Recordemos que, si el informe resulta negativo, la autoridad encargada de la custodia de la grabación debe proceder a su inmediata destrucción.

\footnotetext{
${ }^{33}$ Artículo 5 LOV.
} 
Basta señalar que corresponde a las autoridades que otorguen las correspondientes autorizaciones de uso de videocámaras móviles informar, obligatoriamente, cada quince días a la Comisión sobre la utilización de aquellas, quien puede reclamar y si lo considera oportuno el soporte de las grabaciones para emitir un informe al respecto.

El uso de medios técnicos, carácter público y derechos del público

Nuestro ordenamiento jurídico atribuye carácter público a las cámaras de videovigilancia. Así lo reconoce por lo pronto la LOV. No se trata de un reconocimiento baladí. Tal reconocimiento significa que se concede a los ciudadanos el derecho a obtener información, de forma clara y permanente, sobre la existencia de las cámaras fijas, así como su responsable, sin que sea necesario especificar su emplazamiento. Corresponde a la autoridad que otorgó la autorización cumplir con aquel mandato y hacerla efectiva desde el mismo momento en que se proceda a la utilización de las cámaras, así como mantener actualizada de forma permanente la información. Para cumplir con tal mandato, se utiliza una placa informativa en la que debe figurar el pictograma de una cámara de video y un panel complementario en el que se debe especificar una descripción genérica de la zona de vigilancia, las autoridades responsables de la autorización y la custodia de las grabaciones (el diseño y el formato de la placa se recogen en anexo). Solo por razones debidamente justificadas es posible emplear cualquier otro instrumento de información.

Igualmente, se reconocen al público los derechos de acceso y cancelación de las grabaciones en las que los ciudadanos consideren, razonablemente, que pueden figurar. Recordemos que para ejercitar el derecho de acceso se debe presentar una solicitud adecuada con los requisitos generales establecidos por la legislación general del procedimiento administrativo común, y adjuntar una fotografía, preferentemente de cuerpo entero y, en todo caso, de la cara, así como el día, la hora y el lugar en que consideran presumiblemente fue grabada. La solicitud debe ser contestada en el plazo de diez días contados a partir de la presentación de la solicitud, que puede ser denegada por los responsables de custodiar las imágenes y sonidos, en función de los peligros que pudieran derivarse para la defensa del Estado, la seguridad pública, la protección de los derechos y libertades de terceros o las necesidades de las investigaciones que se estén realizando. 
En su caso, cuando se solicite la cancelación de las imágenes captadas, la autoridad correspondiente debe responder expresamente en un plazo de siete días. Si no se recibe contestación alguna, esta se debe entender estimada.

Igualmente, corresponde a la autoridad informar a los solicitantes si la grabación fue destruida o remitida a las autoridades competentes para sancionar presuntos ilícitos penales o administrativos. Frente a la resolución desestimatoria cabe interponer recurso de alzada, potestativo de reposición y contencioso-administrativo, según el caso.

En este orden de ideas, hay que destacar que, una vez captada y grabada la imagen por cualquiera de estos medios técnicos, si las Fuerzas y Cuerpos de Seguridad comprueban que alguna de aquellas imágenes o sonidos pueden ser constitutivos de un ilícito penal o de una infracción administrativa, deben ponerla a disposición judicial con la mayor inmediatez posible y, en todo caso, en el plazo máximo de setenta y dos horas desde su grabación, o bien, remitir las cintas o grabaciones al órgano competente, igualmente con carácter inmediato, para que se proceda al inicio del oportuno procedimiento sancionador.

Por lo demás, es preciso destacar que las grabaciones realizadas no pueden permanecer guardadas indefinidamente, de tal forma que deben ser destruidas en el plazo máximo de un mes desde su captación, excepción hecha de aquellas que estén relacionadas con infracciones penales o administrativas graves o muy graves en materia de seguridad pública, con una investigación policial en curso o con un procedimiento judicial o administrativo abierto. En orden al cumplimiento de estas obligaciones, existe un órgano responsabilizado en la custodia de las grabaciones y en las tareas de inutilización y destrucción, al cual le corresponde resolver los ejercicios de acceso y cancelación. En todo caso, la destrucción se debe hacer efectiva por cualquier modalidad que permita el borrado o inutilización de las grabaciones, o de las imágenes y sonidos concretos que deban ser cancelados.

Toda personas que por razón del ejercicio de sus funciones tenga acceso a las grabaciones está sujeta al deber de reserva, confidencialidad y sigilo en relación con estas.

\section{Conclusiones}

La seguridad ciudadana u orden público es una actividad dirigida constitucionalmente a la protección de las personas y los bienes, así como al mantenimiento 
de la tranquilidad $\mathrm{u}$ orden de los ciudadanos, y engloba un conjunto plural y diversificado de actuaciones, distintas por su naturaleza y contenido, orientadas a una misma finalidad tuitiva del bien jurídico así definido. El desarrollo de aquella clase de actuación corresponde a un cuerpo concreto habilitado al efecto (Fuerzas y Cuerpos de Seguridad), al que le corresponde proteger el libre ejercicio de los derechos y libertades, es decir, garantizar la seguridad pública. Se trata de un cuerpo especializado en la prevención que debe realizar todas las actividades posibles para proteger e impedir la comisión de infracciones y, en su caso, aplicar las sanciones administrativas correspondientes. En el desarrollo de aquella función, estos cuerpos se pueden valer del uso de los medios tecnológicos que, desde luego, incrementan de manera importante el nivel de protección de los bienes y las libertades personales. Pero aquel uso no puede ser ilimitado hasta tal punto que pueda privar de derechos y libertades a las personas en aras de conseguir un mayor orden público o seguridad ciudadana.

Con la finalidad de conciliar aquellos dos bienes (libertad y seguridad) con el uso de los sistemas de videovigilancia, corresponde llevar a cabo una ponderación sobre el beneficio que aporta el uso de aquellas modernas tecnologías y la eventual restricción de derechos y libertades que supone su empleo. Corresponde, en primer lugar, realizar tal tarea al legislador, quien, con pleno respeto a lo establecido en la Constitución, debe regular los términos que se deben utilizar los sistemas de videovigilancia y ofrecer garantías a la posible restricción de derechos que pueda ser ocasionada como consecuencia del empleo de aquellos sistemas tecnológicos. Esta es la tarea desarrollada por el legislador español con la aprobación de la LOV que, como hemos estudiado, constituye el marco legal aplicable a la utilización de los sistemas de grabación de imágenes y sonidos por las Fuerzas y Cuerpos de Seguridad para proteger el libre ejercicio de los derechos y libertades y garantizar la seguridad. Por medio de aquella norma, el legislador introduce garantías precisas para que el poder público pueda intervenir en el ejercicio de los derechos y las libertades reconocidos en la Constitución en el marco del orden jurídico establecido, de tal forma que este no se pueda ver perturbado por un uso en exceso de aquellos dispositivos tecnológicos bajo el pretexto de la defensa de la seguridad ciudadana.

Pero, en segundo término, es el poder administrativo, conformado por aquellos órganos que autorizan y utilizan los sistemas de videovigilancia, al que le corresponde valorar la proporcionalidad de la medida, de tal forma que el uso de aquella tecnología encuentre un equilibrio de los bienes constitucionales en juego 8libertad 
y seguridad). Por medio de esta ponderación de valores se persigue, fundamentalmente, evitar que las Fuerzas y Cuerpos de Seguridad utilicen la videovigilancia sacrificando injustificadamente los bienes o derechos constitucionales. Para que aquella finalidad sea efectiva, el sistema de ponderación se fortalece por medio de la creación por la LOV de una Comisión de Garantía de Videovigilancia formada por miembros que pertenecen a distintos ámbitos -poder judicial y administrativo- para ofrecer una mayor seguridad. La ponderación debe valorar el principio de proporcionalidad en sus distintas vertientes (necesidad, idoneidad). Si bien la LOV permite la instalación de sistemas de videovigilancia, fijos y móviles a las Fuerzas y Cuerpos de Seguridad, también los sujeta a un régimen de autorización muy estricto, en el que corresponde valorar y justificar las medidas adoptadas y sujetarlas a verificaciones posteriores por las Comisiones y otorgarse por plazos limitados.

Con todo ello se persigue, fundamentalmente, evitar que las Fuerzas de Seguridad Pública utilicen la videovigilancia sacrificando excesivamente los bienes o derechos constitucionales que finalmente quedan garantizado por el control judicial al que puede ser sometida toda la actuación policial para controlar el ajuste legal de las ponderaciones realizadas.

\section{Referencias}

Arzoz Santisteban, X. (2010). Videovigilancia, seguridad ciudadana y derechos fundamentales. Navarra: Thomson Reuteres-Civitas.

De La Iglesia Chamarro, A. (2007). Las comisiones de garantía de la videovigilancia. Revista de Derecho Político, 68, 211-246. Recuperado de http://goo.gl/y42FBr

Goold, B. (2010). Videovigilancia y derechos humanos. En Foro Europeo para la Seguridad Urbana, Ciudadanos, ciudades y videovigilancia. Hacia una utilización democrática y responsable de la videovigilancia (pp. 27-36). París: Foro Europeo para la Seguridad Urbana - STIPA Montreuil.

Martínez, R. (2001). Tecnologías de la información, policía y Constitución. Valencia: Tirant Lo Blanch.

Parejo Alfonso, L. (1996). Manual de derecho administrativo (vol. 2). Barcelona: Ariel.

Parejo Alfonso, L. (2008). Seguridad y policía de seguridad. Valencia: Tirant Lo Blanch.

Parejo Alfonso, L. (2011). Lecciones de derecho administrativo. Valencia: Tirant Lo Blanch.

Ulrich, B. (2000). Retorno a la teoría de la sociedad del riesgo. Boletín de la Asociación de Geográfos Españoles, 30, 9-20 